\title{
PERFIS DISCURSIVOS DA DISCIPLINA DE ENSINO RELIGIOSO NUMA ESCOLA PÚBLICA DA REDE MUNICIPAL DE LIMOEIRO-PE: QUESTÕES ENVOLVENDO LAICIDADE E DIVERSIDADE RELIGIOSA
}

\author{
Aurenéa Maria de Oliveira \\ Maria José Gomes de Sales Neta \\ Universidade Federal de Pernambuco (UFPE), Recife, Pernambuco, Brasil
}

\begin{abstract}
Resumo: O presente artigo tem como objetivo identificar, em uma escola da rede pública da cidade de Limoeiro-PE, os perfis discursivos de docentes que trabalham com a disciplina de Ensino Religioso (ER) sobre Estado laico e pluralidade religiosa. Para tanto, trabalhamos com a metodologia da Análise de Discurso (AD) de linha francesa, cujo intento é examinar a posição dos sujeitos entrevistados segundo as relações de força, lugar e sentido. A discussão teórica apoiou-se nos modelos apresentados por Emerson Giumbelli, a partir de análise das legislações estaduais por ele examinadas, acerca da disciplina em tela: confessional, interconfessional e supraconfessional. Desse modo, foram realizadas três entrevistas semiestruturadas com professores de ER, aliadas à observação participante. Como resultado, verificouse, na escola pesquisada, a presença da ideologia de religiões cristãs neste tipo de ensino, o que implicou em dificuldade de trato com a laicidade e a diversidade religiosa.
\end{abstract}

Palavras-chave: Educação. Ensino Religioso. Laicidade. Diversidade Religiosa.

\section{INTRODUÇÃO}

A temática do Ensino Religioso (doravante ER) é complexa e na conjuntura contemporânea, apesar de inúmeros debates já terem sido estabelecidos no Brasil, desde os tempos do marquês de Pombal, ainda se pergunta sobre a pertinência desse tipo de disciplina nas escolas públicas brasileiras. Em Pernambuco, foi estabelecido, no artigo 1. ${ }^{\circ}$, da resolução do Conselho Estadual de Educação (CEE-PE, 2006a), a não relação entre estado e religiões no que se refere à construção de conteúdos curriculares referentes ao ER em escolas públicas. Neste aspecto, a disciplina, que já era interconfessional e facultativa, em 2012 ganhou neste estado a forma de seminário, sendo ofertada no contraturno escolar. Isso favoreceu a sua evasão e consequente não oferta na rede pública estadual e municipal, dificultando a matrícula dos estudantes (OLIVEIRA, 2016).

Assim, para os que são a favor da manutenção da disciplina como componente curricular das escolas públicas, justificam a sua necessidade afirmando que ela lida com as diferenças e a diversidade, dentre elas a religiosa, nas escolas. Por outro lado, os que 
são contra reafirmam seu passado nos espaços públicos, o proselitismo e a catequese que se associam ao seu ensino em prol principalmente do cristianismo de vertente católica, o que vai de encontro ao Estado brasileiro laico (OLIVEIRA; SILVA, 2012). Diante desses embates, pergunta-se: qual a necessidade desse tipo de ensino nas escolas públicas atualmente? Ele consegue ser laico, respeitando a pluralidade religiosa existente em nosso país? Caso seja dado de forma laica, quais os tipos de conteúdo e de que forma eles são ministrados?

A Constituição Brasileira (CF/88), no art. 210, inciso 1. ${ }^{\circ}$, e a Lei de Diretrizes e Bases (LDBE/96), no art. 33, permitem as escolas ministrarem o ER, desde que ele seja ofertado como optativo e assegurado o respeito à diversidade entre as religiões existentes, sendo tal ensino dado sem proselitismo. Contudo, o Supremo Tribunal Federal (STF) aprovou, em 2017, a promoção de crenças neste componente curricular, dando liberdade ao seu docente de ministrar sua fé. Essa posição do STF acirrou ainda mais os conflitos ao redor da disciplina em tela, pois amplificou o intenso debate já existente (OLIVEIRA; MIRANDA; SILVA, 2018).

Nesse sentido, a partir da decisão mencionada, as escolas públicas podem adotar o ER confessional e a justificativa para isso apoia-se no direito de liberdade de expressão religiosa que o professor tem. O postulado do STF reforça a discussão histórica sobre o $E R$, uma vez que desde o Brasil Império, até os dias atuais, os discursos são configurados e questionam a permanência desta disciplina nos estabelecimentos educacionais não confessionais. Como problemas engendrados por essa discussão, temos: a questão dos conteúdos ministrados e das identidades a serem formadas nesta disciplina; a formação dos docentes e a ministração das aulas. Soma-se a isso, a complexidade da temática em função do pluralismo religioso, sobretudo, em um contexto de predominância histórica das religiões cristãs, como no caso brasileiro (OLIVEIRA; SILVA, 2012; CURY, 2003; DINIZ; LIONÇO; CARREÃO, 2010).

Segundo o censo do IBGE, em 2010, 64\% da população brasileira se declarou católica e $22 \%$ evangélica. Neste aspecto, embora os números dos que se declararam sem religião e de adeptos de outras religiões tenha crescido (IBGE, 2010), em relação ao ER, isso é delicado porque surgem indagações acerca da posição religiosa do docente que ministra as aulas dessa disciplina, no sentido de se a religião a qual ele pertence influencia ou não seus discursos dentro de sala, violando o Estado laico e dificultando o trato com a pluralidade/diversidade religiosa brasileira. Indaga-se isso porque o Ensino Religioso e a diversidade religiosa são temas que não são fáceis de serem trabalhados nas escolas, sobretudo em um país com grande diversidade cultural como o nosso, em que temos vários grupos religiosos, cada um defendendo competitivamente seu credo.

Como o Brasil se afirma laico, o ER não deve, em tese, favorecer nenhuma religião, nem ser ministrado como catequese ou educação religiosa. Todavia, no chão da sala de aula, será que os professores que lecionam essa disciplina não a ministram influenciados por suas ideologias religiosas, transformando o estudo das religiões em um campo do ensino confessional que beneficie certas religiões em detrimento de outras?

Sobre isso, mesmo com a aprovação do ER confessional nas escolas públicas pelo Supremo Tribunal Federal (STF) em 2017, nenhuma escola deveria adotar ou seguir um credo religioso, pois o ambiente educacional público deve promover o respeito à 
diversidade, no caso aqui, à diversidade religiosa (DINIZ; LIONÇO; CARREÃO, 2010).

Trazendo essa discussão acerca do ER para as escolas públicas de Pernambuco, faz-se importante colocar que de modo geral, o estado não possui muitas normatizações sobre o tipo de ensino em questão. Assim, o que existe em termos de legislação é uma resolução deliberada pelo Conselho Estadual de Educação de Pernambuco, datada de 9 de maio de 2006 que, nos artigos $2^{\circ}$ e $3^{\circ}$, afirma que o ER deve ser ofertado pelos sistemas de ensino facultativamente para os alunos e ministrado de modo interconfessional, ou seja, deve ser dado de forma a atender aos interesses das várias confissões, porém sem proselitismo. Isso pode ser conferido no texto abaixo:

Art. $2^{\circ}$ - O Ensino Religioso (ER), parte integrante da formação básica do cidadão, é componente curricular do ensino fundamental das escolas públicas do Sistema de Ensino do Estado de Pernambuco e tem como objeto a compreensão do fenômeno religioso presente historicamente nas civilizações e culturas, expresso em manifestações religiosas. Art. $3^{\circ}$ - O ER, de matrícula facultativa, terá caráter interconfessional e expressará a diversidade culturalreligiosa da sociedade brasileira, distinguindo-se da "doutrinação", nos conteúdos e nos objetivos, excluindo qualquer conteúdo, linha ou forma de proselitismo, garantindo o respeito às crenças de cada indivíduo e o direito subjetivo de não professar qualquer credo religioso (CEE-PE, 2006b).

Fora essa deliberação, não há legalmente mais nenhuma outra legislação que discuta tal questão neste estado. Contudo, apesar de enxuta, a resolução versa sobre quais conteúdos devem ser abordados no ER:

Art. $4^{\circ}$ - Os conteúdos de ER definidos pela escola de acordo com seu projeto político-pedagógico, observando-se as Diretrizes Curriculares Nacionais para o Ensino Fundamental, subordinam-se aos seguintes pressupostos: a) da concepção de conhecimento humano em suas diferentes formas, das relações entre ciência e fé, da interdisciplinaridade e da contextualização como princípios estruturadores da organização curricular; b) da compreensão da experiência religiosa do ser humano, manifesta nas diversas culturas em todos os tempos, reconhecendo o transcendente e o sagrado, através de fontes escritas e orais, ritos, símbolos e outras formas de expressão, identificadas e organizadas pelas tradições religiosas; c) do reconhecimento dos principais valores éticos e morais presentes nas tradições religiosas e sua importância para a defesa e a garantia da dignidade do ser humano, a promoção da justiça e da solidariedade entre as pessoas e os povos, a convivência harmoniosa com a natureza e a criação de cultura de paz; d) da compreensão das várias manifestações de vivências religiosas presentes na sociedade brasileira, cujo conhecimento deve promover a tolerância e o convívio respeitoso com o diferente e o compromisso sociopolítico com a eqüidade social em nosso país; e) do reconhecimento da diversidade de experiências religiosas dos participantes do ambiente escolar e das formas de diálogo 
existentes entre as religiões e destas com a sociedade contemporânea. $\S 1^{\circ}$ - Na vivência da matriz curricular da escola, os conteúdos de ER serão trabalhados de forma articulada com os das outras áreas de conhecimento (CEE, 2006b).

E ainda estabelece o tipo de profissional que deve ministrá-lo:

Art. 5० - A formação dos docentes para o magistério de ER dar-se-á em curso superior de licenciatura em Ciências da Religião ou correspondente, autorizado ou reconhecido pelo sistema de ensino competente. $\S 1^{\circ}-\mathrm{Na}$ falta de professor habilitado nos termos do caput, admitir-se-á para o magistério de ensino religioso, por ordem de prioridade, o que comprove as seguintes condições: $a$. conclusão de curso de bacharelado em Ciências da Religião ou Teologia, autorizado ou reconhecido na forma da lei, e de curso complementar de formação pedagógica devidamente apostilado em seu diploma ou certificado por entidade de educação superior ofertante de curso de licenciatura, integrante de qualquer dos sistemas de ensino; b. conclusão de curso de licenciatura na área de ciências humanas, de pedagogia ou normal superior e de curso de pós-graduação stricto sensu em Ciências da Religião ou similar, autorizados ou reconhecidos por sistema de ensino; $c$. conclusão de curso de bacharelado na área de ciências humanas e de curso de pós-graduação stricto sensu em Ciências da Religião ou similar autorizados ou reconhecidos por sistema de ensino; d. conclusão de curso de licenciatura na área de ciências humanas, pedagogia ou normal superior e de curso de pós-graduação lato sensu em Ciências da Religião, legalmente autorizados ou reconhecidos; e. conclusão de curso de bacharelado na área de ciências humanas e de curso de pós-graduação lato sensu em Ciências da Religião ou similar e também de curso complementar de formação pedagógica devidamente apostilado em seu diploma ou certificado por entidade ofertante de licenciatura integrante de qualquer dos sistemas; f. conclusão de curso livre de bacharelado ou de licenciatura em Teologia, acrescido de curso complementar de formação pedagógica realizado com base no Parecer CNE/CES 063/04, certificado por entidade de educação superior credenciada pelos sistemas de ensino. g. conclusão de curso superior de graduação, legalmente válido e de curso de formação religiosa com carga horária mínima de $\mathbf{1 8 0}$ horas, para ensino nos anos finais do Ensino Fundamental e conclusão de curso normal médio e de curso de formação religiosa com carga horária mínima de 90 horas, para ensino nos anos iniciais, segundo a opção constante no projeto pedagógico da escola (CEE, 2006b).

Diante disso, afirma-se, no entanto, que se no terreno normativo as deliberações sobre o ER se apresentam de forma "razoavelmente objetiva", no terreno das práticas, as atitudes são confusas e desatentas em relação a essa regulamentação, posto que uma 
série de discursos vem sendo acionada, no sentido de se esboçarem processos de disputas que envolvem posições pró e contra o ER. Nesse aspecto, a própria Secretaria de Educação de Pernambuco admitiu, em entrevistas realizadas com alguns de seus representantes, o não acompanhamento ao cumprimento da resolução de 9 de maio de 2006 porque não considerarem prioritário o investimento no ER. Tal postura repercute negativamente nas escolas (OLIVEIRA; SILVA, 2012).

Assim, o espaço educacional, sendo um dos lugares em que os estudantes terão que lidar com múltiplos aspectos culturais, intelectuais, desenvolvendo-se cognitivamente, emocionalmente e politicamente, não deve inibir a liberdade de expressão, invisibilizando certas religiões para favorecer outras. Desse modo, objetivando aprofundar um pouco mais esse debate, este artigo, fruto de orientação de uma pesquisa de Término de Conclusão de Curso em Pedagogia na UFPE, em 2018, e de uma orientação de uma pesquisa PIBIC, financiada pelo CNPq, cujo título foi "TEMAS TRANSVERSAIS E RELAÇÕES DE GÊNERO NO CURRÍCULO DA DISCIPLINA DE ENSINO RELIGIOSO EM ESCOLAS ESTADUAIS E MUNICIPAIS DE RECIFE (2016-2017)", questiona: qual é o perfil da escola e do docente de ER? Se o Brasil é laico, é interessante o professor desta disciplina atuar a partir de seu credo religioso?

Ante o exposto, nosso objetivo geral foi identificar os perfis de professores de ER de uma escola da rede municipal de Limoeiro-PE. A cidade de Limoeiro foi escolhida como lócus de investigação porque uma vez tendo realizado pesquisas sobre essa temática em Recife e Olinda - cidades grandes e centrais da região metropolitana -, resolvemos partir para uma cidade mais afastada, com menor porte e um índice razoável de assunção religiosa cristã entre seus habitantes a fim de verificar se o resultado obtido seria o mesmo apresentando nos lugares anteriormente pesquisados em Pernambuco.

Desse modo, a pesquisa teve a intenção de contribuir para a confecção a posteriori de um mapa acerca do perfil do ER em nosso estado, promovendo uma maior discussão sobre a temática, considerando nesse processo o respeito à laicidade do Estado brasileiro e à questão da diversidade religiosa, como previsto nos códigos legais que regem a sociedade e a educação nacional.

\section{REFERENCIAL TEÓRICO}

\section{Ensino Religioso}

Ao dialogar sobre o ER no contexto da história da educação brasileira, é relevante discutir sobre o processo que vem acontecendo, pois, antes o espaço escolar tinha uma compreensão do ER usado para fins de confissão religiosa, ou seja, o ensino confessional, mas, contemporaneamente, isso tem mudado, apresentando oscilações. Antes o Estado recebia oficialmente a influência da igreja nos espaços públicos, especificamente nas escolas, através de uma educação proselitista; na atualidade, sendo laico, ele não deve, pelo menos em tese, receber tal interferência.

A Constituição Federal, de 1988, e a LDBE, de 1996, preveem que a disciplina de ER corresponde a uma das cinco áreas do conhecimento que fazem parte da base nacional comum curricular. Essa base curricular tem como proposta para a disciplina que manifestações religiosas de diferentes culturas possam argumentar a partir de seus 
princípios éticos, sem privilégio de nenhuma crença.

Todavia, historicamente, desde o Brasil Colonial até o Brasil Império, o ER teve forte influência do cristianismo, especificamente do catolicismo que era a religião oficial. Já no Brasil República, com a educação de tipo humanista, vieram as primeiras ideias sobre laicidade:

A partir da Proclamação da República, em 15 de novembro de 1889, as chamadas tendências secularizantes existentes no império foram assumidas pelo novo regime, organizado a partir do ideário positivista, que, no campo da educação, é responsável pela defesa da escola laica, gratuita, pública e obrigatória, rejeitando, portanto, a ideologia católica que exercia o monopólio do ensino de caráter elitista (JUNQUEIRA; WAGNER, 2011, p. 39).

Contudo, a partir de 1930 é que a luta por uma educação laica no Brasil ocorre com bastante efervescência e dois fatores influenciaram significativamente nesse processo: primeiro, a perda de poder da Igreja Católica sobre o Estado; segundo, pela presença dos escolanovistas no cenário político, defensores de uma perspectiva educacional separada da religião e, consequentemente, do fim do ER (JUNQUEIRA WAGNER, 2011). Diante isso, novas demandas emergiram e transformações ocorreram na oferta e no conteúdo do ER no Brasil, porém esse processo só se consolida na Constituição Brasileira de 1988 (CF/88) e na Lei de Diretrizes e Bases da Educação de 1996 (LDB/96) pois, a partir dessas leis, houve uma abrangência e ampliação do debate sobre a pluralidade em todos os sentidos, inclusive a religiosa, junto à defesa de um ensino não proselitista (DICKIE, 2003).

Assim, o pluralismo religioso foi colocado como um direito, sendo este expresso na Constituição de 1988. Tal ideal era manifesto e defendido por muitas associações interconfessionais do país e, com isso, novos caminhos e sentidos foram atribuídos ao ER.

Contudo, apesar dessas transformações, no contexto atual, O ER, como já mencionado, reflete um campo de intensos debates entre prós e contras a presença da disciplina no espaço público educacional brasileiro (OLIVEIRA; SILVA, 2012). Todo esse debate ocorre porque vivemos em um país com diversas religiões, em que lutas e disputas por espaços de poder emergem entre elas. Como colocado, o acirramento de posições sobre o ER ganhou novos ares recentemente com a decisão do Supremo Tribunal Federal que possibilitou o retorno à lógica confessional desse tipo de ensino. Tal lógica sofre resistência porque, embora se apoie na liberdade religiosa do indivíduo, fere justamente na mesma medida, a partir do momento em que a escola, através de seus professores e gestores, pode fazer proselitismo de determinados credos, ferindo aqueles que não pertençam aos mesmos. Assim, essa decisão do STF vai de encontro à perspectiva daqueles que entendem que o ER nas escolas públicas deve ter caráter laico, entendendo as religiões como culturas, portanto, tratadas como criações humanas e não como fenômenos sobrenaturais (OLIVEIRA, 2016).

O próprio objetivo da disciplina de ER pretende trazer para o campo educacional reflexões sobre costumes, valores e fundamentos das várias religiões que existem em nossa sociedade. Com isso, ela deve explorar nas escolas atividades que tragam o diálogo 
sobre o respeito que deve existir entre as crenças, estabelecendo e promovendo discussões acerca de preconceitos e estigmas culturais advindos de pertenças religiosas (OLIVEIRA, 2016).

1.2 Perfis/Modelos de Ensino Religioso

Como já colocado, o Brasil é um país contemporaneamente laico, o que significa não privilegiar uma religião em detrimento das demais. Com isso, as escolas públicas não devem adotar ou seguir uma crença religiosa, porém isso não as impede de debater a presença religiosa em seu espaço, não descriminando as religiões que existem em nosso país. Para Emerson Giumbelli (2010), ao pesquisar sobre as legislações do ER nos vários estados brasileiros, dentre muitos modelos que encontrou, simplificou, tendo como eixo de apoio essas legislações, os existentes em três (03) perfis principais: o confessional, o interconfessional e o supraconfessional. $\mathrm{O}$ confessional segue a defesa de uma posição religiosa; o interconfessional estabelece como conteúdo válido princípios doutrinários de determinados grupos religiosos com elaboração, por parte desses grupos, de conteúdo programático e curricular para a disciplina; e o supraconfessional, que, estando acima do confessional, adota a defesa do ensino sobre religiões de modo laico, isto é, com investimento na história das religiões e não em dogmas e verdades religiosas. Esses perfis determinam quais assuntos a escola promove/visibiliza e o professor leciona, a partir do modelo que se adota (GIUMBELLI, 2010).

O ER nesta pesquisa é analisado assim, isto é, a partir dos modelos encontrados nas legislações por Giumbelli. Isso não significa que não existam mais tipos e que os aqui trabalhados não dialoguem entre si. Sobre eles, o mesmo autor coloca que os localizou em pesquisa realizada em 2010, na qual examinou os perfis do ER nos estados brasileiros como um todo. Ao final do trabalho, ele afirma que, embora o Brasil se diga laico, no entanto, a maior parte de seus estados não adotou, nas escolas públicas, o modelo supraconfessional tendo em vista sua população ser majoritariamente de credo cristão/católico, com os professores de ER ministrando essa disciplina de acordo com essa religião (GIUMBELLI, 2010).

Quanto aos perfis mencionados, eles expõem algumas situações específicas, sobretudo em São Paulo (SP) e Rio de Janeiro (RJ), discutindo algumas definições e implementações do ER diante do perfil adotado. Assim, coloca que nestes dois estados temos posições extremas, haja vista que no último (RJ), o modelo confessional foi assumidamente adotado, definido pela lei 3.459 de 2000, na qual as aulas foram seguidas por assuntos e professores de uma determinada religião, ou seja, cada aluno em uma sala, para cada religião em todas as modalidades (Fundamental e Médio). Esse modelo confessional assegurou às autoridades religiosas um papel importante (GIUMBELLI, 2010).

Sobre a relação da promulgação dessa lei no Rio de Janeiro com a Igreja Católica, coloca o autor que apesar dela advir maciçamente de segmentos evangélicos, ele enfatiza, contudo, que foi verificada a presença de católicos no processo de sua elaboração. Apesar disso, a disciplina de ER neste estado é facultativa, como na maioria dos estados brasileiros (GIUMBELLI, 2010).

Em São Paulo, adotou-se o perfil oposto, o supraconfessional ou laico, que determina um conteúdo único para a disciplina de ER, sendo este apoiado na história das religiões (sem a presença de religiões ou de religiosos em sua elaboração) e acontecendo somente no Ensino Fundamental. A opção por esse modelo veio a partir de decisão do 
Conselho Estadual de Educação da referida cidade. Entretanto, mesmo com essas duas experiências extremas e diferenciadas, Giumbelli ressalta que o modelo mais adotado nos estados do país é o de cunho interconfessional que possibilita a presença de religiões e religiosos na elaboração de currículos e conteúdos programáticos do $E R$, isso feito sem proselitismo (GIUMBELLI, 2010).

Em Pernambuco, conforme colocado na introdução, o modelo de ER adotado, desde 2006, pelo Conselho Estadual de Educação, é também o interconfessional, mas sem a participação, em teoria, de lideranças religiosas na elaboração curricular da disciplina. Contudo, igualmente como já exposto, o ER é trabalhado de modo precário nesse estado, à medida que não há fiscalização/controle sobre as práticas efetuadas pelos docentes em sala de aula. Também não há na localidade número considerável de capacitações nessa área e quando estas ocorrem, devido ao empenho das secretarias de educação, há resistência por parte dos professores; primeiro, no que se refere ao trato com a diversidade religiosa, segundo, no que diz respeito ao trato das religiões numa perspectiva laica. No mais, podemos acrescentar que, no campo da formação docente, temos em PE uma pós-graduação em Ciências da Religião. Neste caso, tal pós-graduação tem como papel suprir as lacunas desse campo de formação, todavia, ela é ofertada por uma instituição privada confessional, a Universidade Católica de Pernambuco (UNICAP), o que, de antemão, a credencia a não ter grandes compromissos com a laicidade e seus pressupostos.

Em tal cenário, vale sublinhar que vivemos no século XXI, em um país com diversas religiões. Ante esse contexto, a escola pública, como instituição social, deve trabalhar com as várias crenças existentes, mas não as tratando como verdades religiosas e sim como cosmovisões de mundo (OLIVEIRA, 2016; OLIVEIRA; MIRANDA; SILVA, 2018). De fato, a religião faz parte da cultura de estudantes, professores, diretores de escolas etc. e é relevante nos situarmos na sala de aula em torno de seus vários aspectos, entendendo-os como culturais e não como transcendentais, pois:

Prática pedagógica é o termo que designa processos educativos em realização, historicamente situados no interior de uma determinada cultura, organizados de forma intencional, por instituições sociais designadas para isso, implicando práticas diversas, na construção de um conhecimento necessário à atuação social (VIANNA, 2011, p. 70).

Neste aspecto, no modelo de ER adotado pelo professor que ministra essa disciplina, temos igualmente o perfil maior da escola em se tratando da forma como pontos importantes acerca da pluralidade religiosa são compreendidos e debatidos numa perspectiva de construção de um espaço plural, democrático e laico.

\section{MÉTODO}

O discurso é uma ferramenta de exame bastante utilizada no campo metodológico que destaca a linguagem como construtora do social. Para tal, diferentemente da Análise de Conteúdo, o trabalho com ele exige que, por meio da fala, 
situemos o sujeito falante no contexto social e histórico. Assim, a Análise de Discurso (AD) busca a produção enunciativa e, dentro dela, as ideologias (relações de sentido), estas visíveis através das relações de lugar e de força (ORLANDI, 2005). Neste aspecto, as relações de sentido estão onde se formam os discursos, pois não existe "[...] começo absoluto, nem ponto final para o discurso. Um dizer tem relação com outros dizeres realizados, imaginados ou possíveis" (ORLANDI, 2005, p. 39). Essas relações sinalizam para as ideologias atuantes nas falas.

Na relação de força, o lugar do sujeito é o foco central da análise. Essa relação é sustentada pelos diversos poderes que o sujeito ocupa na sociedade posto que ela identifica sua posição e os embates que essa posição trava com outras existentes. Segundo Orlandi (2005, p. 39), "assim, se o sujeito fala a partir do lugar do professor, suas palavras significam de modo diferente do que se falasse do lugar de aluno".

Nas relações de força, também estão presentes os conflitos entre os grupos. Já as relações de lugar dão conta do lugar imaginário que o sujeito pensa/imagina ocupar na sociedade e do lugar, também imaginário, que ele pensa que o outro ocupa socialmente. Elas são chamadas também de relações imaginárias (ORLANDI, 2005). Desse modo, a Análise do Discurso não está ligada à gramática em si, mas sim ao percurso do falado, posto que:

\footnotetext{
[...] não trata da língua, não trata da gramática, embora todas essas coisas lhe interessam [...]. O discurso é assim palavra em movimento, prática de linguagem: com o estudo do discurso observa-se o homem falando (ORLANDI, 2005, p.15).
}

Com isso, percebemos que o discurso está relacionado ao percurso, aos trajetos históricos e políticos que o sujeito trilha. Assim, ele é:

Movimentos dos sentidos, errância dos sujeitos, lugares provisórios de conjunção e dispersão, de unidade e de diversidade, de indistinção, de incerteza, de trajetos, de ancoragem e de vestígio: isto é discurso, isto é ritual da palavra (ORLANDI, 2005, p.10).

O discurso está sempre se movimentando, pois é aberto e dinâmico e seu sentido (significação) depende de suas condições de produção. A partir dessa tendência metodológica, é que as falas dos entrevistados foram analisadas, procurando identificar o perfil do ER ministrado pelo docente da disciplina na escola pesquisada e se os discursos pesquisados visibilizam ou não a diversidade religiosa, levando em conta $\circ$ não proselitismo e o respeito ao Estado laico brasileiro.

Com a finalidade de analisar os discursos dos docentes pesquisados, no caso três (03) professoras de ER, fizemos uso da Análise do Discurso na perspectiva metodológica elaborada por Eni Orlandi. Assim, partimos das concepções históricas, ideológicas e exteriores de discurso e sujeito para compreender, a partir da AD, a realidade por meio da linguagem:

Levando em conta o homem na sua história, a $A D$ considera os processos e as condições de produção de linguagem, pela análise da relação estabelecida pela língua com os sujeitos que falam e a 
situações em que se produz dizer. Desse modo, para encontrar as realidades da linguagem em sua produção, a análise do discurso relaciona a linguagem e sua exterioridade (ORLANDI, 2005, p. 16).

Desse modo, a Análise de Discurso não trata da transmissão da informação, mas da relação de sentido do sujeito, construída por meio do exterior histórico e das relações de lugar e força. Com isso, nosso foco principal nesta pesquisa foi o de analisar a posição dos sujeitos entrevistados a partir das relações de sentido, lugar e força, identificando nas falas o perfil ou modelo adotado na disciplina ER e verificar também o trato com a diversidade religiosa e com as premissas de um Estado laico.

Dado isso, adotamos uma abordagem qualitativa que, segundo Gehdart e Silveira (2009, p. 31), possui como característica a não preocupação "[...] com representatividade numérica, mas, sim, com o aprofundamento da compreensão de um grupo social, de uma organização, etc.". O campo de pesquisa escolhido, como colocado, foi uma escola da rede municipal da cidade de Limoeiro-PE.

Assim, os sujeitos desta pesquisa foram três professoras de ER do Ensino Fundamental I, da rede municipal de Limoeiro, de uma escola da referida cidade. Por uma questão de anonimato, não mencionaremos seus nomes. Também não revelaremos, por questões éticas, o nome da escola pesquisada. A escolha dessa escola se deve ao fato dela oferecer o ER, algo cada vez mais raro no estado de Pernambuco desde 2012, quando essa disciplina passou a ser ofertada na forma de Seminário (OLIVEIRA, 2016).

As entrevistas realizadas com as professoras foram semiestruturadas. Fizemos também observações de suas aulas. Ao longo da pesquisa, utilizamos como material de apoio o gravador, o caderno e o lápis. Autorizada pela professora 1, uma entrevista foi gravada; as outras duas foram anotadas, não tendo sido permitida a gravação. As perguntas foram:

Quadro 1: Perguntas feitas na entrevista

\begin{tabular}{|l|}
\hline Qual o seu nome? \\
\hline Qual a sua formação acadêmica? \\
\hline Você possui alguma especialização? \\
\hline Há muito tempo que leciona a disciplina de ER? Por que resolveu lecionar esta disciplina? \\
\hline Qual sua religião? \\
\hline Você é praticante religiosa? \\
\hline $\begin{array}{l}\text { Qual o perfil que adota na disciplina de ER: confessional/interconfessional/não confessional ou } \\
\text { supraconfessional? }\end{array}$ \\
\hline O que você entende por Ensino Religioso? \\
\hline $\begin{array}{l}\text { Você segue a base curricular nacional para abordar a disciplina ER, ou seja, a ministrar sem } \\
\text { proselitismo, respeitando a laicidade do Estado brasileiro? }\end{array}$ \\
\hline Quais conteúdos são trabalhados na disciplina ER? \\
\hline Quais são os materiais metodológicos usados? \\
\hline Qual modelo acha que seria o mais correto para o Ensino Religioso? Justifique. \\
\hline Qual sua opinião sobre o ER dado de modo confessional em escolas públicas? \\
Fonte: elaboração das autoras.
\end{tabular}


Também usamos, como ponte de apoio para o recolhimento de dados, a observação participante das aulas dadas pelas três (03) professoras entrevistadas. Nessa observação, a nossa prioridade foi analisar, de modo mais direto, o campo pesquisado:

\begin{abstract}
A técnica de observação participante se realiza através do contato direto do pesquisador com o fenômeno observado para obter informações sobre a realidade dos atores sociais em seus próprios contextos. [...] estabelecendo uma relação face a face (MINAYO, 2009, p. 59).
\end{abstract}

\title{
RESULTADOS E DISCUSSÃO
}

Antes de apresentarmos os discursos das professoras entrevistadas para análise, sublinhamos algumas observações feitas em suas aulas de ER:

Professora 01 - Em algumas das aulas assistidas dessa docente, anotamos os seguintes procedimentos: a professora iniciava seu trabalho fazendo a oração do Pai Nosso; em seguida, explanava o amor de Deus a todas as coisas e pessoas, sem exceções. A partir daí, ela promovia um diálogo entre os alunos sobre o respeito às diferenças. Esse diálogo era pautado, no entanto, pelo amor cristão, católico e sobrenatural, com forte carga proselitista. Em outra aula assistida, após a oração, ela entregou tinta e papel para os discentes a fim de que eles fizessem desenhos de Jesus Cristo e seus discípulos reunidos. No fim desse dia, todos cantaram a música "Deus é amor".

Professora 02 - Foi observado nas aulas dessa docente que, de início, ela promovia o debate sobre o respeito à diversidade religiosa na sociedade. Entretanto, a noção de respeito era norteada pelo horizonte da construção da paz numa perspectiva de paraíso cristão. Em outra aula, essa professora pediu que os estudantes expressassem no papel o que entendiam por respeito; após a escrita, ela abriu a roda de conversa sobre o que é diversidade religiosa e explicou que, na sociedade, existem pessoas que tem outra religião sem ser a católica e a evangélica, porém não citou o nome dessas outras religiões.

Professora 03 - Na única aula que observamos dessa professora, ela escreveu no quadro as palavras: "Deus", "Carinho" e "Vida". Em seguida, ela entregou para os alunos o poema "No jardim do Amor", para depois trabalhar sua leitura coletivamente. Ao final, explanou sobre o quanto Deus é bom, porque ele fez e faz muitas coisas bonitas na vida das pessoas.

Partindo agora para a parte metodológica propriamente dita, reiteramos que, para o exame das falas, utilizaremos a Análise de Discurso (AD) elaborada por Eni Orlandi, para investigar, no discurso das professoras entrevistadas, as relações de lugar, força e sentido. Essas relações, junto à escolha teórica adotada dos perfis de ER (confessional, interconfessional e supraconfessional) apresentadas por Giumbelli (2010), a partir das legislações estaduais existentes nos vários estados brasileiros que investigou, auxiliaramnos a entender o trato com a diversidade religiosa e a questão da laicidade na disciplina em pauta.

Segundo Orlandi (2005), o discurso trabalha com a memória histórica que é formada por processos polissêmicos e parafrásticos. Por paráfrase, entende-se no dizer 
um sentido ideológico que se mantém; por polissemia, um sentido que se desloca. Através da fala da professora 01, percebemos esses processos, sobretudo o parafrástico, no que diz respeito ao perfil ideológico confessional adotado por ela em suas aulas de ER. Esse perfil é identificado através de relações de lugar e de força, nas quais a entrevistada alça a Bíblia ao status de livro didático e as figuras de Deus e Jesus Cristo a conteúdos programáticos centrais de seu trabalho:

Eu uso a bíblia, trabalho com base na apresentação sobre Jesus [...]. A gente procura focar em Deus, que Deus é aquele que cura, que salva e que Deus é único. Deus é a base de tudo e numa disciplina de Ensino Religioso não poderíamos deixar de falar dele (Professora 01).

Após examinar a fala dessa professora, buscando identificar as relações de sentido, percebemos que a professora 01 expressa uma ideologia cristã atuante em seu trabalho como docente com o ER na sala de aula. Como colocamos, a relação de sentindo está associada às ideologias dos sujeitos e, segundo Orlandi (2005, p. 46), “[...] a ideologia faz parte, ou melhor, é a condição para a construção do sujeito e dos sentidos". Em outra fala, da mesma docente, notamos um discurso de respeito à diversidade religiosa, porém perpassado por valores cristãos:

Não tenho todos os assuntos na memória, mas me lembro de... A importância do diálogo entre religiões; assunto sobre respeito; sobre um ajudar o outro como Cristo ensinou; assuntos como somos todos iguais e outros que não me lembro, mas tudo que ensino, tem Deus e Jesus Cristo como norte (Professora 01).

Em outra entrevista, agora com a professora 02 , identificamos que o perfil adotado em suas aulas de ER não é diretamente confessional, pois notamos em sua fala a importância de se ressaltar a imparcialidade no trato com as religiões e com a diversidade religiosa em sala de aula:

Acredito que com o ensino confessional aprovado vamos retroceder no tempo. Sabe que existe uma diversidade de religiões, culturas etc... O professor deve apresentar todas para o conhecimento do aluno, para que o mesmo tire suas próprias conclusões... O professor não deve impor sua religião como a melhor em sala de aula e sim ter uma postura imparcial, neutra dentro do âmbito escolar (Professora 02).

Porém, mais adiante, quando lhe perguntamos sobre quais conteúdos são ministrados em suas aulas e o material utilizado, esbarramo-nos com a ideologia cristã novamente, concebida como salvadora das almas humanas e minimizadora de conflitos:

Eu trabalho com os conteúdos bíblicos, ensino o amor do evangelho porque neste mundo que a gente vive, só esse amor une, salva e promove paz. Tá certo que não sou conhecedora de outras religiões 
que não sejam cristãs, mas acredito que nenhuma tem uma máxima maior como a que Cristo nos ensinou de "amai ao próximo como a ti mesmo" e é disso que o mundo precisa (Professora 02).

A fala da professora 03 corrobora as falas anteriores, expondo que o perfil discursivo das docentes de ER na escola pesquisada é o de modelo confessional que confunde ER com educação religiosa, numa violação evidente às noções de laicidade defendidas pelo Estado brasileiro:

[...] Eu me adéquo ao perfil confessional, embora eu respeito às demais religiões não cristãs. Se o perfil confessional é o que ensina o amor cristão, me enquadro neste sim (Professora 03).

Em outro discurso, que aborda a questão do Estado laico, mesmo reconhecendo que o perfil confessional não é o mais adequado ao espaço público, por ferir a diversidade religiosa, a professora, todavia, justifica-se através da afirmação de que a escola pública e o Estado brasileiro nunca foram laicos, reafirmando sua ideologia cristã:

[...] Pra escola pública, por ensino público, acredito que o perfil não confessional seja o mais adequado, mas o Brasil nunca foi laico, aqui isso nunca pegou, veja pela nossa cédula, nas repartições públicas e escolas que possuem sempre um crucifixo, uma imagem católica. Acho que está na nossa formação o catolicismo e não vejo mal nisso, porque não defendemos o ódio e sim o amor de Cristo (Professora 03).

Sobre a diversidade religiosa, ela coloca:

É fato que a escola pública tem que lidar com a diversidade religiosa e o respeito a todas as religiões, mas, isso é preocupante, porque a maioria de nós não conhece todas as religiões, nem tem preparo adequado para isso, daí todo mundo ensinar o que sabe que é o cristianismo (Professora 03).

Neste aspecto, faz-se importante ressaltar que as três (03) docentes entrevistadas se afirmaram católicas praticantes e possuem formação em Letras. Elas afirmaram que escolheram ministrar a disciplina de ER para complementar a carga horária e também porque esse era o espaço para se falar sobre o amor de Cristo.

Diante disso, percebemos que, neste espaço escolar público pesquisado, na cidade de Limoeiro, em Pernambuco, existe um ER de modelo confessional cristão, que apresenta como reflexo as dificuldades de se lidar com a diversidade religiosa e com o Estado laico. Nesse sentido, alguns aspectos observados no dia a dia da sala de aula corroboram esse resultado, tais como: o uso da oração cristã do Pai Nosso antes de se entrar na sala de aula; a presença de Crucifixo na escola; a utilização de músicas religiosas cristãs nas aulas de ER.

Ainda sobre isso, percebemos, através das posições de sujeito (professoras católicas) exibidas nos discursos, as relações de sentido materializadas na ideologia catequética cristã atuante nas aulas de ER da escola pesquisada. Assim, a aprovação pelo 
STF do ER confessional, no qual o professor pode pregar sua fé nas escolas públicas, inibe o trabalho com outras crenças na sala de aula que não a cristã, reforçando a violação aos princípios do Estado laico e aos princípios de respeito à diversidade religiosa. Isso, reiteramos, fere a atual Constituição de 1988 e a LDB de 1996, à medida que não valoriza a pluralidade religiosa e o preceito laico do não proselitismo.

Observamos também, a partir dos discursos das professoras, que elas trabalham o respeito cristão que uma religião deve ter para com a outra, mas nenhuma delas trabalha a noção de respeito nos vários tipos de religiões existentes no Brasil, em seus costumes e raízes como, por exemplo, o Candomblé, a Umbanda, o Islamismo, o Budismo, o Espiritismo etc.

\section{CONSIDERAÇÕES FINAIS}

Segundo a Lei de Diretrizes e Bases da Educação de 1996, o Ensino Religioso faz parte das áreas de conhecimento existentes nas escolas públicas. Neste aspecto, tal disciplina tem como um de seus objetivos dialogar com as várias cosmologias religiosas no sentido de promover o respeito à pluralidade e às diferenças religiosas, isto feito, repetimos, sem a prática do proselitismo.

Entretanto, essa pesquisa, que teve como fim identificar, através dos discursos de professoras de ER de uma escola pública municipal da cidade de Limoeiro-PE, o perfil adotado por elas e pela escola, verificando se o modelo adotado neste tipo de ensino favorece ou não o trato com a diversidade religiosa e a não catequese. Após a análise, verificamos o contrário, isto é, existe uma tendência confessional de ER com benefício para a religião cristã de cunho católico.

Os resultados do trabalho sinalizam para o fato de que os sujeitos da pesquisa entrevistados não conseguiram se desvencilhar da ideologia de pertença religiosa que possuem, haja vista que as professoras entrevistadas são católicas e todas elas adotam o modelo confessional de abordagem do ER que, como salienta Giumbelli (2010), existe no país, desde os tempos coloniais. A decisão do Supremo Tribunal Federal, em 2017, de permissão do ER de cunho proselitista preocupa mais ainda esse contexto, tendo em vista que compromete o trato igualitário com as diversas religiões na escola, o que, por sua vez, não só compromete a pluralidade religiosa, como a própria democracia em si, à medida que determinadas crenças são invisibilizadas, enquanto outras são colocadas como verdadeiras e universais.

Assim, na contemporaneidade, diante desse cenário, considerando que o ER é complexo e não unânime, indagamos sobre sua importância nos dias de hoje, especialmente na escola pública. Em nosso processo de pesquisa, por meio dos perfis discursivos organizados no corpus das entrevistas semiestruturadas, verificamos com a ajuda da metodologia da Análise de Discurso que as professoras entrevistadas se aliam a uma ideologia cristã ainda fortemente presente neste tipo de ensino. Desse modo, na escola pesquisada, usam a relação de lugar ocupada por elas como docentes, para difundirem suas crenças religiosas, numa exímia relação de força que privilegia suas crenças pessoais em detrimento das crenças e valores religiosos ou não, dos estudantes.

Destarte, isso obstaculiza o trato com a diversidade religiosa posto que inibe o 
trabalho com a democracia religiosa, à medida que se expõe apenas um credo, estabelecendo-o como único, verdadeiro, tendo ele que ser aceito em sala de aula por todos. Neste aspecto, isso vai de encontro à postura laica que entende as religiões como sendo parte da cultura, devendo, portanto, serem investigadas, sobretudo na escola pública, seja como conteúdo do ER ou de qualquer outra disciplina, como parte da história humana e não como elemento transcendental e metafísico. Pois, nesta última apreensão se envolvem noções do que é certo e errado, o que pode remeter a posições não democráticas e intolerantes em relação à fé do outro (OLIVEIRA, 2016).

Desse modo, a cultura de um indivíduo é parte constituinte de sua identidade, e essa identidade só pode ser construída em meio e junto às diferenças, e todos nós temos uma identidade diferenciada que deve ser respeitada. Sendo assim, a escola pública, como um espaço plural e democrático, deve abordar todas as cosmologias religiosas, assumindo a diversidades neste campo:

\begin{abstract}
É pertinente compreender que a escola, local socialmente aceito para o desenvolvimento do processo ensino-aprendizagem, espaço de fomento e apreensão de saberes socialmente construídos, estabelece relações com o campo religioso (OLIVEIRA, 2016, p.131).
\end{abstract}

Assim, é também dentro da sala de aula que se constrói a identidade/cultura dos alunos e essa construção identitária envolve elementos culturais de pertença religiosa. Neste aspecto:

\begin{abstract}
[...] a constituição de toda identidade se dá a partir dessa fronteira de diferenças entre nós e o outro, por isso entende-se que na sala de aula, a oferta da disciplina de Ensino Religioso, se constitui em espaço adequado para que as diversidades se estabeleçam, mediante discussões sobre os fenômenos religiosos, isso feito sem a presença da intolerância e do proselitismo (OLIVEIRA, 2016, p. 131).
\end{abstract}

Contudo, não foi à ausência do proselitismo a que as conclusões de nossa pesquisa chegaram, pois, opostamente, as docentes do trabalho entrevistadas, como trouxemos, adotam perfis de cunho confessional, tratando a disciplina de ER como espaço para a ampliação da ideologia e dos valores cristãos católicos, sem alusão a outras cosmologias religiosas. Assim, a partir do exame de seus discursos, percebemos a ideologia religiosa delas atuando em suas abordagens nas aulas de ER. Com isso, compreendemos que a escola pública, entendida aqui como espaço privilegiado, posto que ela deve proporcionar debates, entre outros, sobre a diversidade religiosa numa perspectiva laica, fica comprometida no seu trato com as diferenças e com a democracia. 
DISCURSIVE PROFILES OF THE RELIGIOUS EDUCATION DISCIPLINE IN A PUBLIC SCHOOL OF THE LIMOEIRO-PE MUNICIPAL NETWORK: ISSUES INVOLVING LAITY AND RELIGIOUS DIVERSITY

\begin{abstract}
This article aims to identify the discursive profiles of teachers working with the Religious Education (RE) discipline on secular state and religious plurality in a public school in the city of Limoeiro-PE. To do this, we worked with the French Line Discourse Analysis (AD) methodology to examine the position of the subjects interviewed according to the relations of force, place and meaning. Already the theoretical discussion was based on the models presented by Emerson Giumbelli, based on an analysis of the state legislations he examined, about the discipline on the screen: confessional, interconfessional and supraconfessional. Thus, three semi-structured interviews were conducted with RE teachers, together with participant observation. As a result, the presence of the ideology of Christian religions in this type of teaching was verified at the school, which implied difficulties in dealing with secularity and religious diversity.
\end{abstract}

KEYWORDS: Education. Religious Education. Laicity. Religious Diversity.

\title{
PERFILES DISCURSIVOS DE LA DISCIPLINA DE ENSEÑANZA RELIGIOSO EN UNA ESCUELA PÚBLICA DE LA RED MUNICIPAL DE LIMOEIRO-PE: CUESTIONES ENVIANDO LAICIDAD Y DIVERSIDAD RELIGIOSA
}

RESUMEN: El presente artículo tiene como objetivo identificar, en una escuela de la red pública de la ciudad de Limoeiro-PE, los perfiles discursivos de docentes que trabajan con la disciplina de Enseñanza Religiosa (ER) sobre Estado laico y pluralidad religiosa. Para ello, trabajamos con la metodología del Análisis de Discurso (AD) de línea francesa con el fin de examinar la posición de los sujetos entrevistados según las relaciones de fuerza, lugar y sentido. La discusión teórica se apoyó en los modelos presentados por Emerson Giumbelli, a partir de análisis de las legislaciones estatales por él examinadas, acerca de la disciplina en pantalla: confesional, interconfesional y supraconfessional. De este modo, se realizaron tres entrevistas semiestructuradas con profesores de ER, aliadas a la observación participante. Como resultado, se verificó en la escuela investigada, la presencia de la ideología de religiones cristianas en este tipo de enseñanza, lo que implicó en dificultad de trato con la laicidad y la diversidad religiosa.

PALABRAS CLAVE: Educación. Educación Religiosa. Secularismo. Diversidad Religiosa.

\section{REFERÊNCIAS}

BRASIL. [Constituição de (1988)]. Diário Oficial [da] República Federativa do Brasil, Poder Executivo, Brasília, DF, 5 out. 1988. Disponível em: http://www.planalto.gov.br/ccivil_03/Constituicao/ConstituicaoCompilado.htm. Acesso em: 27 abr. 2018.

BRASIL. Lei n 9.394, de 20 de dezembro de 1996. Estabelece as Diretrizes e Bases da 
Educação Nacional. Diário Oficial [da] República Federativa do Brasil, Poder Executivo, Brasília, DF, 23 dez. 1996. Disponível em: http://portal.mec.gov.br/arquivos/pdf/ldb.pdf. Acesso em: 28 out. 2018.

CONSELHO ESTADUAL DE EDUCAÇÃO DE PERNAMBUCO. Resolução CEE/PE no 1, de 31 e janeiro de 2006. Secretaria de Educação de Pernambuco, Recife, 31 de janeiro de 2006a. Disponível em: http://www.cee.pe.gov.br/wpcontent/uploads/2015/08/RESOLU\%C3\%87\%C3\%83O-CEE-PE-N\%C2\%BA-01-2006.pdf. Acesso em: 25 out. 2018.

CONSELHO ESTADUAL DE EDUCAÇÃO DE PERNAMBUCO. Resolução $n^{\circ} 5$ de 9 de maio de 2006. Dispõe Sobre a Oferta de Ensino Religioso nas Escolas Públicas Integrantes do Sistema de Ensino do Estado de Pernambuco. Presidente: Antônio Inocêncio Lima. Diário Oficial do Estado, Pernambuco, 05 mai. 2006b, p. 16-17.

CURY, C. R. J. Ensino Religioso e Escola Pública: o curso histórico de uma polêmica entre igreja e Estado no Brasil. Revista de Educação, n. 17, p. 20-37, 1993.

CURY, C. R. J. Ensino Religioso na Escola Pública: o retorno de uma polêmica recorrente. Revista Brasileira de Educação, n. 27, p. 183-213, 2004.

DICKIE, M. A. S. Todos os Caminhos Levam a Deus: O CONER e o ensino religioso em Santa Catarina, Brasil. Encontro Anual da ANPOCS, n. XXVII, Caxambu, 2003.

DINIZ, D.; LIONÇO, T.; CARRIÃO, V. Laicidade e EnsinoReligioso no Brasil.Brasília, UNESCO, Editora UnB, 2010.

GEHDART, T. E; SILVEIRA, D. T. (Orgs.). Métodos de Pesquisas. Porto Alegre, Editora da UFRGS, 2009.

GIUMBELLI, E. Ensino Religioso em Escolas Públicas no Brasil: notas de pesquisa. Rio de Janeiro: [s.n], 2010. Disponível em: https://seer.ufrgs.br/debatesdoner/article/view/7280. Acesso em: 25 jan. 2018.

IBGE, 2010. Disponível em: http://www.ibge.gov.br/home/estatistica/populacao/censo2010/. Acesso em: 05 jul. 2018.

JUNQUEIRA, S.; WAGNER, R. O Ensino Religioso no Brasil. Curitiba, Champagnat, 2011.

MINAYO, M. C. de S. (Org.). Pesquisa Social: teoria, método e criatividade. Petrópolis, Rio de Janeiro, Editora Vozes, 2009.

OLIVEIRA, A. M. de; SILVA, D. E. da. Alteridade X Intolerância: diretrizes curriculares que podem embasar mais democrática e pluralmente o Ensino Religioso. Revista Teias, Rio de Janeiro, v.13, n.27, 139-160, jan/abr. 2012. 
OLIVEIRA, A. M. de. Diferença Sexual e Religiosa no Currículo de Ensino Religioso em Escolas de Recife. Revista Eletrônica de Educação, São Carlos, v. 10. n. 1, p. 128-142, 2016.

OLIVEIRA, A. M. de; MIRANDA, M. H. G. de; SILVA, M. A. M. P. da. Questões de Gênero e Sexualidade no Espaço Público tendo como Eixo de Debate a Disciplina de Ensino Religioso em Escolas Públicas de Recife. ETD - Educação Temática Digital, Campinas, São Paulo, n. 4, p, 864-886, out/dez. 2018.

ORLANDI, E. P. Análise de Discurso: princípios e procedimentos. $6^{a}$ ed. Campinas, São Paulo, Pontes, 2005.

VIANA, F. S.A Prática Docente e o Uso da Imagem: estudo de caso de um professor de História. 2011. 120 f. Dissertação (Mestrado em Educação). Universidade Federal de Pernambuco, Recife, 2011.

\footnotetext{
AurenÉa Maria de OlivelRA: É licenciada em História pela Universidade Federal Rural de Pernambuco (UFRPE/1996), mestre em Ciência Política pela Universidade Federal de Pernambuco (UFPE/2001) e doutora em Sociologia pela Universidade Federal de Pernambuco (UFPE/2006). É pós-doutorada pela Pontifícia Universidade Católica do Paraná em área de concentração Educação, Sexualidades e Religião (2014-2015). Atualmente é professora associada da UFPE, Centro de Educação, Departamento de Fundamentos Sócio-Filosóficos da Educação. É também professora permanente do Programa de Pós-Graduação em Educação da UFPE (Núcleo de Teoria e História da Educação) e líder do Grupo de Estudo em Religiosidades, Educação, Memórias e Sexualidades (UFPE) cadastrado no CNPq.

Orcid: https://orcid. org/0000-0003-1033-4015

E-mail: aurenea@yahoo.com.br
}

Maria José Gomes de Sales Neta: Graduada em Pedagogia pela Universidade Federal de Pernambuco.

Orcid: https://orcid.org/0000-0002-3659-5806

E-mail: mariajose20@outlook.com.br

Este periódico utiliza a licença Creative Commons Attribution 3.0, para periódicos de acesso aberto (Open Archives Iniciative - OAI). 